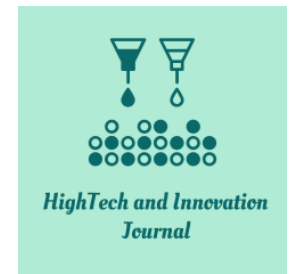

ISSN: 2723-9535

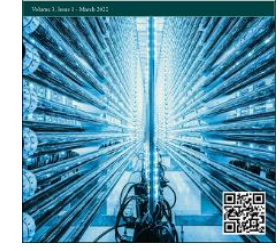

\title{
Innovation for People with Disabilities in Hospitality Industry: A Theoretical Approach
}

\author{
Nikolaos Theocharis ${ }^{{ }^{*}}$, Helen Catherine Leligou ${ }^{2}{ }^{\circ}$, Dimitrios Tseles ${ }^{2}{ }^{\circ}$ \\ ${ }^{I}$ Department of Tourism Professions, Advanced School of Tourism Education, Rhodes, Greece. \\ ${ }^{2}$ Department of Industrial Design and Production Engineering, University of West Attica, Aigaleo, Greece.
}

Received 13 November 2021; Revised 12 January 2022; Accepted 18 January 2022; Published 01 March 2022

\begin{abstract}
Hotels are forms of businesses connected to the entire system of production and distribution of tourist products. Essentially, they provide hospitality goods and services to travelers, individuals with different profiles and interests, and thus play a very important role in the tourism sector. Therefore, the purpose of the article is to point out the theoretical approach of innovation in the context of its utilization in hotels for individuals with disabilities. We have reviewed the existing theoretical approaches to innovation and then analyzed their applicability in the tourism sector. Based on the findings, we developed theoretical approaches, such as the coupling theory and the innovation diffusion theory, that can be applied to the target sectors and provide valuable insights to the relevant actors. Research shows that innovation, whether it concerns technological applications or processes, affects the enrichment of hotel services provided for people with disabilities and influences the technical-functional and organizational processes of hospitality. On this basis, innovation is a key factor of growth for any hotel, as it increases its competitiveness and sustainability through the utilization of the potential provided by the use of new innovative technological applications or processes for people with disabilities.
\end{abstract}

JEL Classification: L83, O30.

Keywords: Tourism; Hotel; Innovation; Hospitality; Individuals with Disabilities Service Delivery.

\section{Introduction}

This article deals with the theoretical approach of innovation in terms of its use for individuals with disabilities in hotels. So, what relevant research on tourism and individuals with disabilities has been carried out? In international literature, research on tourism for individuals with disabilities mainly focuses on accessibility and travel behaviour. In terms of accessibility issues, research is related to online access to information resources [1-6], the limitations of individuals with disabilities in tourism activity [7-11], as well as the barriers that individuals with disabilities face [12, 13]. Also, in terms of travel behavior issues, research is related to the analysis of the needs and motivations of people with disabilities [14-18], the evaluation of the behavior of tourists with disabilities [19-23], the evaluation of information sources for accommodation [24-26], and the evaluation of hospitality services in specific tourist destinations [27-31]. At this point, it should be underlined that the term "accessibility" does not only mean hotel facilities but also services and goods that enable people with disabilities to function autonomously in the environment [32]. On this basis, when this article refers to innovative technological applications or processes for individuals with

* Corresponding author: ntheoharis@aster.edu.gr

dol) http://dx.doi.org/10.28991/HIJ-2022-03-01-010

$>$ This is an open access article under the CC-BY license (https://creativecommons.org/licenses/by/4.0/).

(C) Authors retain all copyrights. 
disabilities, as they appear in the hotel, all these innovations are meant to enable them to function autonomously in an environment, regardless of whether these innovations are also used by other individuals. Furthermore, when reference is made to individuals with disabilities, it means individuals (a) with mobility impairments, (b) with visual impairments, (c) with hearing impairments, (d) with perception disabilities, (e) with mental or cognitive disabilities, (f) with speech impairments, and (g) with other disabilities and chronic diseases [32].

The methodology we have followed is depicted in the following Figure 1 and includes four steps. We have first reviewed the existing theoretical approaches of innovation and then we analysed their applicability in the tourism sector. Based on the results, we concluded with the theoretical approaches that can be applied to the target sectors and enable the relevant actors obtain valuable insights.

\begin{tabular}{|c|c|}
\hline $\begin{array}{c}\text { Review of the } \\
\text { Innovation theories }\end{array}$ & $\begin{array}{c}\text { Evaluation of the } \\
\text { results }\end{array}$ \\
\hline $\begin{array}{c}\text { Analysis of their applicability } \\
\text { on the tourism sector }\end{array}$ & $\begin{array}{c}\text { Selection of the theoretical models that } \\
\text { can be adopted in the target domain }\end{array}$ \\
\hline
\end{tabular}

Figure 1. Research Methodology

\section{Conceptual Approaches and Categorizations of Innovation}

A literature review on the classification of innovation has demonstrated several approaches. According to Sundbo \& Gallouj (1999), service innovation can be classified into four types: product innovation, process innovation, organizational innovation, and market innovation [33]. These researchers describe organizational innovations as "new general forms of organization or management such as introduction of TQM, self-steering groups, etc.". They also argue that process innovations are renewals of the prescriptive procedures for producing and delivering the service, and fall into two categories: innovation in production processes (back office) or innovation in service delivery processes (front office).

According to Prahalad \& Hamel (1990), Meneses \& Texeira (2011), Booyens \& Rogerson (2016), innovation may relate to the technology of production and distribution of a product or service through the market, in this case the hotel market [34-36]. More specifically, the main types of innovation as they appear in the hospitality industry are described as follows (Figure 2) [37]:

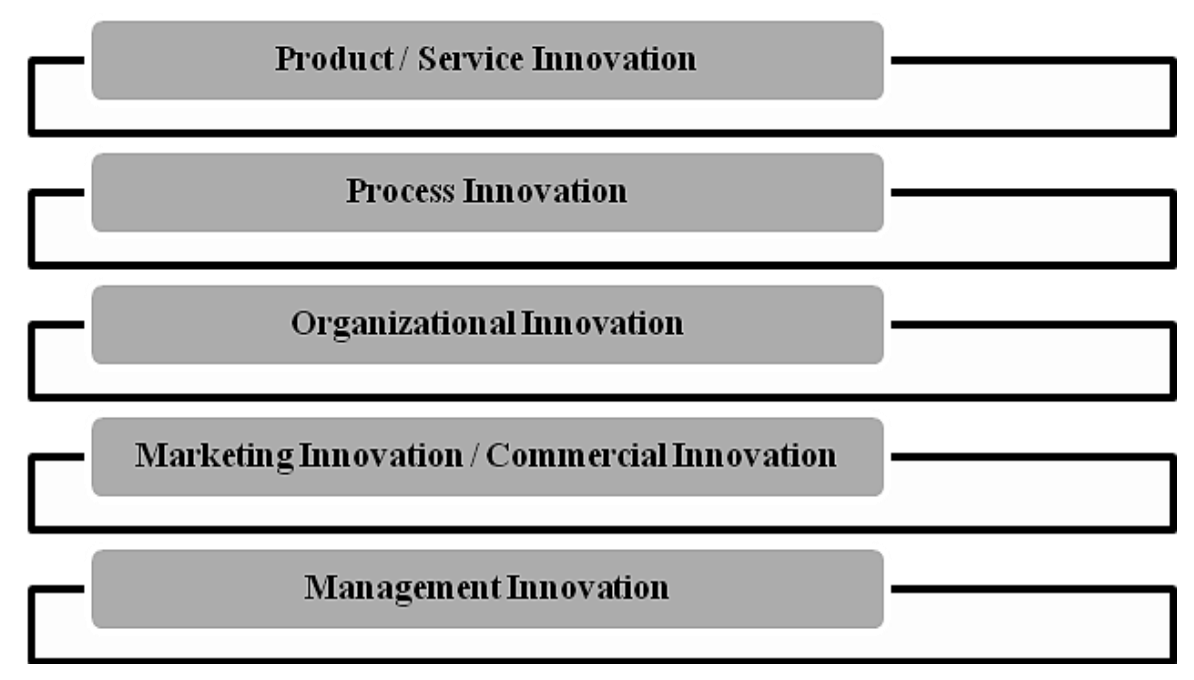

Figure 2. Types of Innovation in Hospitality Industry

\subsection{Product / Service Innovation}

Product innovation is the introduction to the market of a product that is new or significantly improved in terms of its characteristics or intended uses. This includes significant improvements to its technical specifications, its component parts, embedded software (if any) and other functional characteristics. The term "product" refers to a good or service. A good is usually a tangible object, such as a device, software program, etc. A service is usually intangible, such as online room reservations, advice on the facilities of an accommodation, etc. 
The innovations of a product, whether it is a new product or an improved one, must be new to the hotel, but not necessarily to the hotel industry or the specific market. In particular, they may relate to goods or services appearing in the hotel for the first time, or to goods or services that have been significantly improved. It could also relate to goods or services that have been originally developed by other hotels but are being used or sold for the first time by a particular hotel. A typical example of product/service innovation could be the international Accor hotel group. These hotels started to provide low cost services without differentiating their basic quality features (basic hotel standards), such as the level of cleanliness, bed comfort, accessibility, etc. [38, 39]. Moreover, as mentioned by Reiwoldt (2006) and Penner et al., (2013), the differentiation of small accommodations and their design in terms of services provided and pricing have consisted important product features of the functional characteristics of hotels [40, 41]. In addition, several studies in the hotel sector refer to the "unique qualities" of the services provided that are considered as innovative, e.g. animation, gastronomy, wellness facilities, etc. [42-44], in terms of comfort [45, 46] or environmental measures [47-49].

\subsection{Process Innovation}

Process innovation refers to a new production process or the improvement of an existing one. Its main characteristics are an increase in productivity, a reduction in costs and an increase in employee job satisfaction. In hospitality businesses such as hotels, process innovation enables them to introduce new services in the customer service departments, particularly in the Rooms Division (e.g. reception, housekeeping, etc.), catering departments, etc., or existing services with significant improvements-changes in processes and techniques (workflow and dataflow, task assignment, etc.), technology and equipment (e.g. new hotel software).

Undoubtedly, implementing an innovative process is difficult, and depends on the changes that are usually made to the hotel's organizational structure and management systems. Some research approaches to process innovation refer to the stages of technology utilization and its gradual evolution in tourism, and tourist accommodation in particular. For example, Yuan et al. (2006) created a model plan of information and communication technology (ICT) implementation in terms of customer hospitality, and pointed out that the potentials of technology are addressed and modified according to the organizational characteristics and management objectives of the tourism business [50]. In addition, Eurotel Hospitality (2019) presented an innovative locking system (VingCard Allure) with a unique, flexible design, incorporating more features than most high-end locking systems on the market [51]. This innovative system incorporates the most advanced wireless locking solutions, including RFID locking technology, is compatible with Mobile Access and operates as an independent mechanism with individual functions (bell, room number, notices such as "make up my room, do not disturb", etc.).

\subsection{Organizational-Managerial Innovation}

It is the application of a new organizational method to the business practices of the hotel industry, in the workplace, organization and external relations. Essentially, it is the introduction of a new way of communication, as well as the application of new methods in hotel management.

A typical example of organizational innovation is the application, for the first time, of methods to develop and reinforce the hotel employee loyalty, such as training and education systems (e.g. Employee training and education in the rooms department). Leidner (1993) and Pasquier (2015) describe the innovations of McDonald's restaurants. More specifically, they mention well-designed training of managers and employees, public relations, internal promotion and reinforcement of corporate values. As they mention, many companies, such as Disney, have tried to adopt and further develop the McDonald's restaurants' methods [52, 53].

\subsection{Marketing Innovation / Commercial Innovation}

Implementing a new marketing method that involves significant changes in the design of products or services, their positioning, promotion and pricing. Marketing innovations are mainly related to various business partnerships, especially in the gastronomy and tourism sectors. Wine marketing, for example, is often related to marketing of a specific tourist destination or a specific hotel business [54-56]. Also, another typical example of marketing innovation is Instagram's collaboration with hotels, which has established a strong relationship with the target market. Instagram has already implemented several innovative marketing practices that improve the experiences of its users. Therefore, this social media platform has enabled hotels to increase the "depth of the narrative" as well as the individual's experience [57]. Through the "explore" feature, personalized channel results are displayed, followed by the ability to record time-lapse videos. Leading international brands operate on this platform, which supports its validity through an advertising and marketing channel. 


\subsection{Management Innovation}

This type of innovation includes the processes of designing new products and services, quality control processes, as well as processes of redesigning the business in order to reduce production and operating costs. The fact is that corporate reorganization provides a further incentive to create. Changing work structures in a hotel is often a stimulus for employees (at all levels) for improvement and renewal. At the same time, conditions for alertness and intensified effort are created in order to achieve the set goals. A typical example of management innovation in the hotel is the "Touch + Dine" application, which provides simultaneous information at multiple points, such as the reception department, the Restaurant Manager, the F\&B Manager and the hotel's management on the status of reservations by day and time, allowing them to better organize the kitchen, the staff, the supply of materials and even better distribution of guests to all restaurants. The specific features of the application initially help to maximize revenue in the hotel's food service departments, while creating the conditions for efficient operation of other departments (e.g. Rooms Division) [58].

In conclusion, the article focuses on Product/Service Innovation (PSI). This does not mean that there are not - or may not appear - innovative technological applications for people with disabilities in the future that involve some other type of innovation.

\section{Theoretical Approaches of Innovation}

Tourism, like services in general, is characterised by a high degree of heterogeneity. For example, hotel complexes and resorts with golf courses cannot be compared with a family-run guesthouse or small restaurants. Some innovation surveys have shown that hotels and restaurants have a lower sustainability rate. These are usually businesses with a very low barrier to entry, thus facilitating the creation of new businesses on a non-innovative basis $[33,59,60]$. Research on innovation in tourism reveals different approaches; for example, some studies focus on measuring innovation [61-65], on innovation patterns [66-71], and on the analysis of the determinants of innovation [43, 72-78]. The following theoretical approaches are related to technology, which includes innovation. Essentially, these are theoretical approaches that relate to the interpretation of innovation, both in goods and services provided.

\subsection{Wilson's Theory of Innovation}

Wilson's (1966) theoretical approach to innovation states that innovation takes place in the following three stages [79]:

- Conception of change: this is the primary stage of innovation in business.

- Proposing the change: refers to a cost-benefit analysis of the potential innovation by individuals making organizational decisions. If the potential benefits appear to exceed the costs, then the innovation will be proposed for adoption.

- Adoption and implementation of the change: this is mainly a political process characterised by a "bargaining" between the proponents of the innovation and the voucher takers, in order to gain the necessary support to accept the innovation.

This theoretical approach mainly refers to the economic cost-benefit analysis of the potential innovation by the hotel management. It is a realistic approach for the current hotel industry, and several hotel managers follow this particular economic screening process for the implementation - or not - of innovative technological applications. However, given that our research concerns services provided by the hotel company to people with disabilities through innovative technological applications or processes, the aforementioned does not reveal the stage of feedback and refeedback from this category of customers, an important element in terms of the innovative process.

\subsection{Shepard's Theory of Innovation}

Shepard (1967), on the other hand, describes three stages [80]. The first stage involves the initial conception of the idea which is usually done by a business executive person. The second stage involves the acceptance of the idea which requires persuasion, integration and dominance on the part of the managers advocating the innovation in order to gather the critical support for its acceptance. Finally, the third stage involves implementation, which involves making innovation part of an established operating procedure of the organization.

This theoretical approach mainly refers to the process of adoption of the innovation on the part of the hotel manager as well as his/her actions for the final acceptance and implementation in the hotel. It is a more peopleoriented approach to the adoption of innovation in the hotel. Of course, it should be noted that the stages described do not include an economic analysis of the project. Also, this theoretical approach does not mention the stage of feedback and customer feedback (in this case, people with disabilities), an important element in terms of the innovation process. 


\subsection{Tornatzky's et al. Theory of Innovation}

Tornatzky et al. (1983), in a review of the literature on innovation under the auspices of the National Scientific Foundation, describe five general stages of innovation. These stages are as follows [81]:

- Awareness or initial recognition of a new idea by the business managers;

- Identification, selection and adaptation of a new idea to the needs of the organization;

- Adoption - commitment to the innovation;

- Implementing of the innovation, and;

- Routinisation of the new idea as an evolving feature of the business.

This theoretical approach follows processes that may be applicable to the field of our research on people with disabilities. In any case, the economic analysis of the proposed innovation is considered necessary for the final decision of its implementation. In addition, following the stage of implementing the innovation for people with disabilities in the hotel and identifying it as an evolving feature of its operation, the stage of feedback and refeedback from the specific category of customers is considered necessary to complete the innovation process.

\subsection{The Theoretical Two-stage Model for Innovation}

Another theoretical approach that of Damanpour (1987), Van de Ven and Rogers (1988), Rogers (1995), and Marcus and Weber (2000), involves a two-stage model [82-85]. According to this, there is an innovation introduction stage consisting of all activities related to identifying the problem, collecting information, forming and evaluating attitudes towards the problem, and seeking appropriate resources. The processing of all these elements leads to the decision to implement the innovation or not. The second stage is that of the implementation of the innovation and consists of all the events and actions related to the initial deployment and continued use of the innovation until it becomes an element of the "routine" of the organization.

This theoretical approach is essentially a "coupling" of the theory of Tornatzky et al. [81], where the five (5) general stages of innovation are eventually formed into two (2), without any apparent reduction of the individual activities and processes involved in innovation. As already pointed out in previous theoretical approaches, the stage of feedback and refeedback from customers (people with disabilities) is considered essential for the completion of the innovation process.

\subsection{The Coupling Theory of Innovation}

This theoretical approach, also known as the "coupling model", refers mainly to the fact that innovation appears as a logical sequence of events, but does not evolve as a continuous process and is subject to feedback [86]. The coupling model is illustrated in Figure 3.

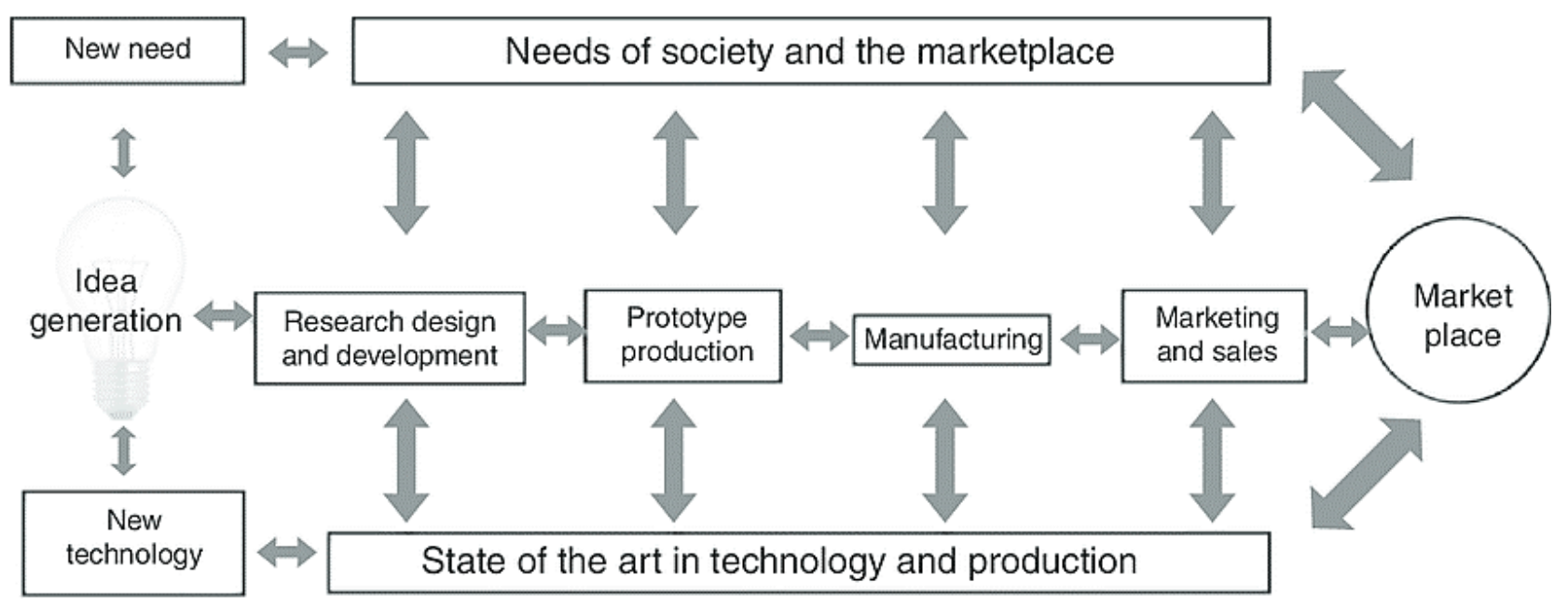

Figure 3. Coupling model of innovation (Adapted from Rothwell (1994) [86])

This theoretical approach follows processes that can be applied to the field of our research on individuals with disabilities. The continuous feedback of the main stages of the model contributes substantially to the flexibility and adaptability of the individual parts to the requirements and the satisfaction of the specific needs of individuals with disabilities. According to Rothwell (1994), since the mid-1990s, organizations have remained committed to technology, strategic networking has been a key feature, and the pace of the market has increased. In addition, 
organisations are increasingly pursuing better and more integrated production and sales strategies, with greater flexibility and adaptability.

It also argues that "rapid innovation" is an important factor determining corporate competition. The ability to control rapid product development and use can be considered an important key parameter of the innovation process. Table 1 below provides a comprehensive overview of the knowledge required to apply Rothwell's specific model.

Table 1. Sources of knowledge for the application of the Rothwell model (Adapted from Rothwell (1994) [86])

\begin{tabular}{ll}
\hline \multicolumn{1}{c}{ Knowledge from internal sources } & \multicolumn{1}{c}{ External or shared internal / external knowledge } \\
\hline Research and development - Learning through the development process & Learning from suppliers \\
Learning through the various tests & Learning from key users \\
Learning through development - Learning through production & Learning from "horizontal" partners \\
Learning through failures & Learning through research and technology infrastructures \\
Learning through vertically organized enterprises & Learning from literature \\
& Learning from the competitors' actions \\
& Learning through technological barriers \\
& Learning through the new applications or from the new staff \\
& Learning through customers - according to prototype tests \\
& Learning through the services provided - product disapproval findings
\end{tabular}

In conclusion, this theoretical approach follows procedures that can be applied in the field of our research and more specifically in the utilization of innovations for individuals with disabilities in the hotel. The continuous feedback of the main stages of the model contributes substantially to the flexibility and adaptability of the individual parts to the requirements and the satisfaction of the specific needs of people with disabilities.

\subsection{The Innovation Diffusion Theory}

The specific theoretical approach of technology diffusion theory seeks to identify the characteristics of a technology that are perceived and could influence its adoption by users [84, 87]. Innovation diffusion is defined as the way in which technological innovations of products and processes are disseminated, from the moment of their first global implementation, to different countries and regions, as well as to different markets and firms, through commercial and other channels [37]. Essentially, if there is no diffusion, technological product and process innovations will have no economic impact. Another definition of diffusion of innovation is that it is a process in which the innovation spreads from its source of creation to its final user and in this process of transmission of the idea or technique, there is interaction between the one who disseminates it and the recipient.

The difference between the concepts of adoption and diffusion is that diffusion occurs between individuals or other units in a region, whereas adoption is a matter of one individual or unit. Essentially, diffusion is the time evolution of the adoption rate of an innovation which can be described by an S-Curve [84] (Figure 4).

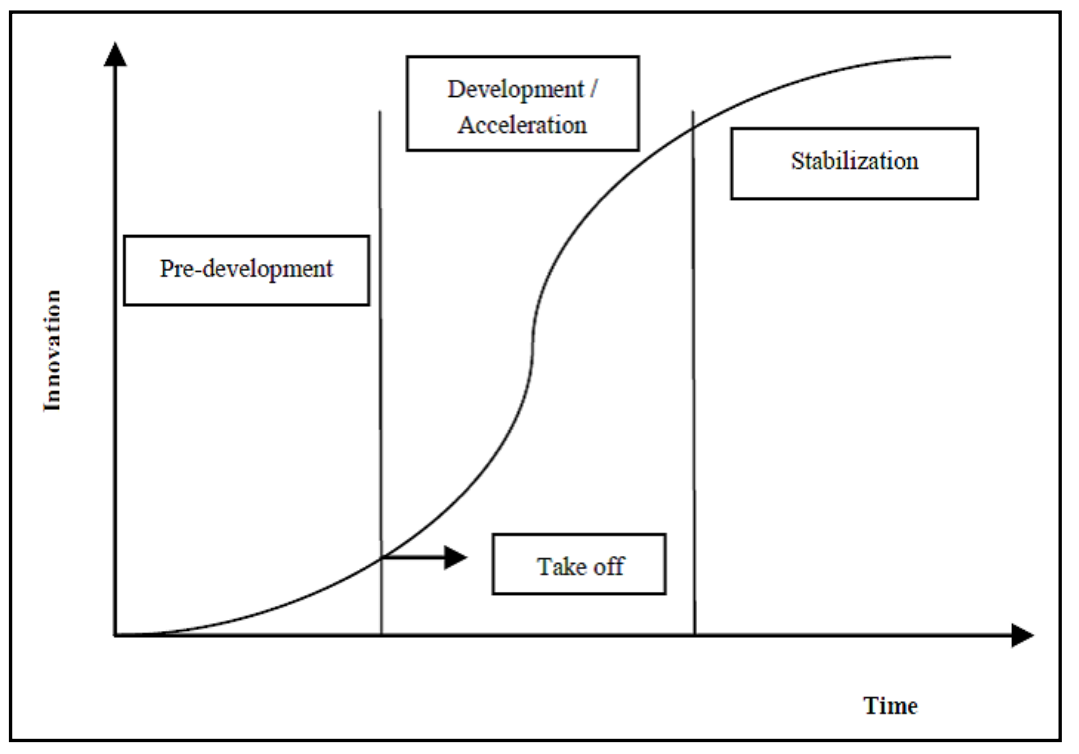

Figure 4. S-Curve of Innovation (S-Shaped) (Adapted from Rogers (1995) [84]) 
According to Rogers (1995), the following elements can be distinguished in the diffusion process [84]:

(a) Innovation: The diffusion rate will be higher if the recipients perceive that the innovation:

- Has a comparative advantage;

- Is compatible;

- Is not too complex;

- It must be possible to test it;

- The effects of adoption must be visible.

(b) Communication Channels: Diffusion is a process of communication about the innovation between two subjects, the first having knowledge and the second being unaware of its existence. The transmission from one to the other takes place through the following communication channels:

- Mass communication channels;

- Interpersonal communication channels.

(c) Time: It is not whether the innovation is used for the first time that matters, but rather the perception of the subject. Therefore, the adoption process is influenced by:

- Knowledge about the innovation:

(1) Awareness of its existence;

(2) Knowledge of how it is used;

(3) Knowledge of its existence;

(4) Knowledge of how it works.

- Persuasion of a favorable attitude towards its use;

- Decision to commit resources for its adoption;

- Implementation of the innovation;

- Confirmation of the decision based on positive results.

(d) The Social System: The structure of the social system (varying over time) affects the diffusion process in the following ways:

- The social structure;

- By the social structure.

On the basis of the above, the Technology Acceptance Model (TAM) was designed to bring together a number of suitability factors of technological systems, allowing predictions to be made about their acceptance and further use $[88,89]$. In particular, this model predicts user acceptance based on the influence of two factors: perceived usefulness and perceived ease of use. In terms of perceived usefulness, this is defined as the degree to which an individual believes that using a particular system will enhance his or her performance, while in terms of perceived ease of use, this is defined as the degree to which the individual believes that using a particular system will be effortless. According to this model, these factors influence the formation of users' attitudes, which in turn determines behavioural intentions to use a system.

\subsection{Other Theoretical Approaches to Innovation}

Several authors argue that competitiveness in tourism depends mainly on innovation to achieve lower costs and higher quality outcomes [74, 90]. In hospitality business, Jones (1996), suggests that innovation takes the form of a gradual process due to the influence of personal contact with the customer [72]. In this case, a new service is designed and control requires the input of future customers (e.g. people with disabilities), but also the active cooperation of the hotel staff that will eventually provide the service. Ottenbacher and Gnoth (2005) did not elaborate a theory of innovation development, but proposed nine factors that support the success of service innovation by hotel managers: market selection, strategic human resource management, employee training, market responsiveness, empowerment, behavioural evaluation, marketing synergy, employee engagement and tangible quality [74]. These factors are listed in order in a way that could also be treated as stages in the development of innovation for people with disabilities. 
In the same context, the research by Orfila-Sintes and Mattsson (2009) does not propose a theory but studies the factors of innovation [91]. Specifically, by investigating tourism firms in transport, accommodation, entertainment and intermediation sectors, they conclude that innovation in the industry is related to factors, such as the service provider, customer capabilities (e.g. people with disabilities), market factors and the impact of innovation on performance. The important thing about this research is that it introduces a new element to innovation, and this relates to the perception of innovation from the perspective of service providers in the industry. Perhaps this element also supports the findings of Camison and Monfort-Mir (2012), who argue that the diffusion of innovation among service and tourism firms is characterised by a low propensity to develop new products and processes [63]. The question in simple terms is whether it is the adoption of innovation that creates this low propensity. Grissemann et al. (2013) investigating innovation in hospitality business identified five internal dimensions that determine innovation: employee involvement, customer involvement (e.g. individuals with disabilities), ICT, innovation management and network innovation. The same research also reveals that innovations at hotel service and hotel IT were influenced by employee envolvement, customer participation, innovation management and ICT [92].

All of the above-mentioned issues relate to the development and of new products, but they may well also apply to services in the hotel sector. There is undoubtedly scope for innovation and the current pace of technological development to develop and improve existing products and services, as well as to introduce new products, production methods, services, techniques and organizational processes. Essentially, innovation is the process of turning an idea into a product or service to be introduced for the first time or developing new or improved processes (streamlining innovation upon its reintroduction). It is a key factor for any business as it greatly increases the viability of the business while reducing business risk.

The question that arises at this point is which theoretical approach was applied in this research. First of all, it should be noted that the approaches are not incompatible with each other. That is, they are not detached and completely different from each other. For example, Rothwell's (1994) approach refers to sources of knowledge acquisition which can be competitors, customers, suppliers, employees, etc. [86], while the approach of Grissemann et al. (2013) refers to the perception of innovation which is heterogeneously defined by both staff and customers [92]. In essence, the two theoretical approaches differ only in that the former talks about information while the latter talks about information processing. Therefore, referring to only one theoretical approach may be restrictive. In conclusion, this research can draw on many elements of Rothwell's (1994) approach [86]. Rothwell studies the whole sequence of events, evolving as a continuous process subject to feedback and involving innovation, from concept and design to development and sale. Also, this research can draw on a significant part of Rogers' (1995) approach as it refers to knowledge of innovation, comparative advantages of innovation adoption and innovation communication channels which are elements of this research [84]. Finally, this article refers to the approach of Grissemann et al., (2013) who investigate the perception of innovation in hospitality firms and how it is shaped [92].

\section{Conclusion}

In this article, the definition of innovation as well as the theoretical approaches related to innovative technological applications in hotels were attempted. Undoubtedly, innovation, as well as the fast development of technology, have scope in the evolution and improvement of a hotel's existing products and services, as well as in the introduction of new products, hospitality services, and technical-functional and organizational processes, both for people with disabilities and for other customers. It is the process of transforming an idea into a product or service that is being adopted for the first time or developing new or improved processes. In conclusion, there is plenty of scope for future research, as the elements that make up new technology, tourism, and people with disabilities are numerous, complex, and, in some cases, multi-level. The needs that arise daily from people with disabilities in the hotel compose a new operating framework that must be differentiated and adapted according to the services provided and the human resources of the organization. On this basis, innovation is a key component of growth for any hotel, as it greatly increases the competitiveness and sustainability of the business while at the same time reducing business risk. Moreover, by definition, disability in relation to hotel hospitality is a huge challenge for the future, particularly in terms of its social dimension and the use of innovation in hotels.

\section{Declarations}

\subsection{Author Contributions}

N. T. performed the bulk of the research work, on the analysis of the theories and on the literature review; E.A.L. contributed to the review of the results and the evaluation of the innovation theories and D.T. contributed in the concept of the work and in the editing of the paper. All authors have read and agreed to the published version of the manuscript.

\subsection{Data Availability Statement}

Data sharing is not applicable to this article. 


\subsection{Funding}

The authors received financial support for the publication of this article from the Master programme "Product and Service Automation" organized by University of West Attica, Greece.

\subsection{Institutional Review Board Statement}

Not Applicable.

\subsection{Informed Consent Statement}

Not Applicable.

\subsection{Declaration of Competing Interest}

The authors declare that they have no known competing financial interests or personal relationships that could have appeared to influence the work reported in this paper.

\section{References}

[1] Williams, R., Rattray, R., \& Grimes, A. (2007). Online Accessibility and Information Needs of Disabled Tourists: a Three Country Hotel Sector Analysis. Journal of Electronic Commerce Research, 8(2), 157-171.

[2] Theocharis, N. (2020). Innovative Technological Applications for People with Disabilities in Rooms Division of Greek Hotels. Doctoral Dissertation, University of the Aegean, Mytilene, Greece.

[3] Smieszek, M. (2020). What content is published on websites of organizations supporting people with disabilities? Secondary analysis of online sources. Niepełnosprawność i Rehabilitacja, 4, 12-21.

[4] Epuran, G., Tecău, A. S., Constantin, C. P., Tescașiu, B., \& Chițu, I. B. (2020). Opportunities of Using New Technologies (Vr/Ar) in Order To Facilitate the Access of Persons with Disabilities to Tourist Products. Series V - Economic Sciences, 13(62)(2), 55-64. doi:10.31926/but.es.2020.13.62.2.6.

[5] Singh, R., Ismail, A., PS, S., \& Singh, D. (2020). Compliance of accessibility in tourism websites: a pledge towards disability. Journal of Hospitality and Tourism Insights, 4(3), 263-281. doi:10.1108/JHTI-05-2020-0092.

[6] Teixeira, P., Eusébio, C., \& Teixeira, L. (2021). Website accessibility in the hospitality industry: A study in the central region of Portugal. International Journal of Tourism Policy, 11(3), 222-246. doi:10.1504/IJTP.2021.118666.

[7] Daniels, M. J., Drogin Rodgers, E. B., \& Wiggins, B. P. (2005). "Travel Tales": An interpretive analysis of constraints and negotiations to pleasure travel as experienced by persons with physical disabilities. Tourism Management, 26(6), 919-930. doi:10.1016/j.tourman.2004.06.010.

[8] Popiel, M. (2016). Tourism Market, Disability and Inequality: Problems and Solutions. Acta Academica Karviniensia, 16(3), 25-36. doi:10.25142/aak.2016.022.

[9] Kaganek, K., Ambroży, T., Mucha, D., Jurczak, A., Bornikowska, A., Ostrowski, A., Janiszewska, R., \& Mucha, T. (2017). Barriers to Participation in Tourism in the Disabled. Polish Journal of Sport and Tourism, 24(2), 121-129. doi:10.1515/pjst2017-0013.

[10] McKercher, B., \& Darcy, S. (2018). Re-conceptualizing barriers to travel by people with disabilities. Tourism Management Perspectives, 26, 59-66. doi:10.1016/j.tmp.2018.01.003.

[11] Gillovic, B., \& McIntosh, A. (2020). Accessibility and inclusive tourism development: Current state and future agenda. Sustainability (Switzerland), 12(22), 1-15. doi:10.3390/su12229722.

[12] Yfantidou, G., Spyridopoulou, E., Papaioannou, A., \& Balaska, P. (2017). Service innovation in hotels for people with disabilities. 20th Excellence in Services International Conference, September 7 and 8, 835-848, Verona, Italy.

[13] Bianchi, P., Cappelletti, G. M., Mafrolla, E., Sica, E., \& Sisto, R. (2020). Accessible tourism in natural park areas: A social network analysis to discard barriers and provide information for people with disabilities. Sustainability (Switzerland), 12(23), 1-14. doi:10.3390/su12239915.

[14] Darcy, S. (2002). Marginalised participation: Physical disability, high support needs and tourism. Journal of Hospitality and Tourism Management, 9(1), 61-72.

[15] Son, A. (2010). Developing a Barrier-Free Tourism : Making a City of Guangzhou a Better Tourism Destination for All. Social Research in Transport (SORT) Clearinghouse, 1-11.

[16] Mamoon, A. (2013). Disability Tourism: Why do Disabled People Engaging in Tourism Activities? European Journal of Social Sciences, 39(3), 480-486. 
[17] Kim, S., \& Lehto, X. Y. (2013). Travel by families with children possessing disabilities: Motives and activities. Tourism Management, 37, 13-24. doi:10.1016/j.tourman.2012.12.011.

[18] Gonda, T. (2021). Travelling habits of people with disabilities. Geojournal of Tourism and Geosites, 37(3), 844-850. doi:10.30892/GTG.37315-717.

[19] Burnett, J. J., \& Baker, H. B. (2001). Assessing the travel-related behaviors of the mobility-disabled consumer. Journal of Travel Research, 40(1), 4-11. doi:10.1177/004728750104000102.

[20] Daruwalla, P., \& Darcy, S. (2005). Personal and societal attitudes to disability. Annals of Tourism Research, 32(3), 549-570. doi:10.1016/j.annals.2004.10.008.

[21] Kalargyrou, V., Barber, N. A., \& Kuo, P. J. (2018). The impact of disability on guests' perceptions of service quality delivery in the hospitality industry. International Journal of Contemporary Hospitality Management, 30(12), 3632-3655. doi:10.1108/IJCHM-06-2017-0362.

[22] De Pascale, A., Meleddu, M., \& Abbate, T. (2021). Exploring the propensity to travel of people with disabilities: a literature review. In SSRN Electronic Journal. doi:10.2139/ssrn.3832082.

[23] Rubio-Escuderos, L., García-Andreu, H., Michopoulou, E., \& Buhalis, D. (2021). Perspectives on experiences of tourists with disabilities: implications for their daily lives and for the tourist industry. Tourism Recreation Research, 1-15. doi:10.1080/02508281.2021.1981071.

[24] Darcy, S. (2010). Inherent complexity: Disability, accessible tourism and accommodation information preferences. Tourism Management, 31(6), 816-826. doi:10.1016/j.tourman.2009.08.010.

[25] Wee, S. T., \& Sanmargaraja, S. (2016). Accessible Information required by the Independent Disabled Tourists: A Mini Review. Australian Journal of Basic and Applied Sciences, 10(1), 65-70.

[26] Teixeira, P., Eusébio, C., \& Teixeira, L. (2021). How diverse is hotel website accessibility? A study in the central region of Portugal using web diagnostic tools. Tourism and Hospitality Research, 14673584211022796. doi: $10.1177 / 14673584211022797$.

[27] Ozturk, Y., Yayli, A., \& Yesiltas, M. (2008). Is the Turkish tourism industry ready for a disabled customer's market?. The views of hotel and travel agency managers. Tourism Management, 29(2), 382-389. doi:10.1016/j.tourman.2007.03.011.

[28] Grady, J., \& Ohlin, J. B. (2009). Equal access to hospitality services for guests with mobility impairments under the Americans with Disabilities Act: Implications for the hospitality industry. International Journal of Hospitality Management, 28(1), 161-169. doi:10.1016/j.ijhm.2008.06.013.

[29] Stathoglou, O. Perspectives of Accessible Tourism: Investigation of Infrastructure and Services at Accommodation Units in the Region of Crete. Doctoral Dissertation, University of the Aegean, Mytilene, Greece.

[30] Kiriya, G. (2020). The City of Athens as Accessible Tourist Destination: An Empirical Exploration; Doctoral Dissertation. University of West Attica, Athens, Greece.

[31] Stankova, M., Amoiradis, C., Velissariou, E., \& Grigoriadou, D. (2021). Accessible Tourism in Greece: a Satisfaction Survey on Tourists With Disabilities. Management Research and Practice, 13(1), 5-16.

[32] Mizamtsi, S., Nikolaides, E., \& Mourouzis, A. Accessibility for All (A4ALL): Pilot Study on Accessibility to Local and Regional Authorities in Greece-Bulgaria Cross-Border Area. In National Confederation of Disabled People - Branch of Northern Greece \& National Council of People with Disability in Bulgaria - Branch of Haskovo, Bulgaria.

[33] Sundbo, J., \& Gallouj, F. (1999). Innovation in Services In seven European Countries. Synthesis Report for European Commission, DG, XII(1), 42. Available online: https://rucforsk.ruc.dk/ws/portalfiles/portal/3678896/CSS_Rapport_1.pdf (accessed on May 2021).

[34] Prahalad, C. K., \& Hamel, G. (2009). The core competence of the corporation. Knowledge and Strategy, 68(3), 41-60. doi:10.1016/b978-0-7506-7223-8.50003-4.

[35] Meneses, O., \& Teixeira, A. (2011). The innovative behaviour of tourism firms. Economics and Management Research Projects: An International Journal, 1(1), 25-35.

[36] Booyens, I., \& Rogerson, C. M. (2016). Unpacking the geography of tourism innovation in Western Cape Province, South Africa. In D. Szymańska \& R. K (Eds.), Bulletin of Geography, 31(31) 19-36. doi:10.1515/bog-2016-0002.

[37] Oslo Manual, (2005). Guidelines for collecing and interpreting innovation data (3rd Ed.). OECD Publishing, Paris, France.

[38] Ren, L., Qiu, H., Wang, P., \& Lin, P. M. C. (2016). Exploring customer experience with budget hotels: Dimensionality and satisfaction. International Journal of Hospitality Management, 52, 13-23. doi:10.1016/j.ijhm.2015.09.009. 
[39] Hall, C. M., \& Williams, A. M. (2019). Tourism and innovation. In Tourism and Innovation (2nd Ed.), 1-480. doi:10.4324/9781315162836.

[40] Riewoldt, O. (2006). New Hotel Design. Laurence King Publishing, London, United Kingdom.

[41] Penner, R. H., Adams, L., \& Robson, S. (2013). Hotel design, planning and development WW Norton \& Co, New York, United States

[42] Jacob, M., Tintoré, J., Aguiló, E., Bravo, A., \& Mulet, J. (2003). Innovation in the tourism sector: Results from a pilot study in the Balearic Islands. Tourism Economics, 9(3), 279-295. doi:10.1177/135481660300900303.

[43] Pikkemaat, B. (2008). Innovation in Small and Medium-Sized Tourism Enterprises in Tyrol, Austria. The International Journal of Entrepreneurship and Innovation, 9(3), 187-197. doi:10.5367/000000008785096601.

[44] Gyurácz-németh, P., Friedrich, N., \& Clarke, A. (2013). Innovation in Special Hotels - As a Key to Success. International Conference, 19(20), 643-653.

[45] Enz, C. A., \& Siguaw, J. A. (2003). Revisiting the Best of the Best: Innovations in Hotel Practice. Cornell Hotel and Restaurant Administration Quarterly, 44(5-6), 115-123. doi:10.1177/001088040304400516.

[46] Liechty, T., Yarnal, C., \& Kerstetter, D. (2012). “I want to do everything!” Leisure innovation among retirement-age women. Leisure Studies, 31(4), 389-408. doi:10.1080/02614367.2011.573571.

[47] Le, Y., Hollenhorst, S., Harris, C., McLaughlin, W., \& Shook, S. (2006). Environmental management: A study of Vietnamese hotels. Annals of Tourism Research, 33(2), 545-567. doi:10.1016/j.annals.2006.01.002.

[48] Chou, C. J., Chen, K. S., \& Wang, Y. Y. (2012). Green practices in the restaurant industry from an innovation adoption perspective: Evidence from Taiwan. International Journal of Hospitality Management, 31(3), $703-711$. doi:10.1016/j.ijhm.2011.09.006.

[49] García-Pozo, A., Sánchez-Ollero, J. L., \& Ons-Cappa, M. (2016). ECO-innovation and economic crisis: a comparative analysis of environmental good practices and labour productivity in the Spanish hotel industry. Journal of Cleaner Production, 138(1), 131-138. doi:10.1016/j.jclepro.2016.01.011.

[50] Yuan, Y. L., Gretzel, U., \& Fesenmaier, D. R. (2006). The role of information technology use in American convention and visitors bureaus. Tourism Management, 27(2), 326-341. doi:10.1016/j.tourman.2004.12.001.

[51] Vingcard. Vingcard Allure Brochure. Available online: https://eurotel.gr/en/\%CF\%80\%CF\%81\%CE\%BF\%CF\%8A\% CF\%8C\%CE\%BD/vingcard-allure/ (accessed on April 2021).

[52] Leidner, R. (1993). Fast Food, Fast Talk. In University of California Press. University of California Press, California, United States.

[53] Pasquier, M. (2015). McDonald's digital innovation strategy: building the restaurant of the future as a startup. Available online: https://www.innovationiseverywhere.com/mcdonalds-digital-innovation-strategy-building-the-restaurant-of-the-futureas-a-startup/ (accessed on April 2021).

[54] Carlsen, J., \& Charters, S. (2006). Global Wine Tourism: Research. Management and marketing, CABI, Cambridge, USA.

[55] Ndou, V., Del Vecchio, P., Passiante, G., \& Schina, L. (2012). Toward a sectoral system of innovation for local wine sector. International Journal of Business and Globalisation, 8(1), 81-94. doi:10.1504/IJBG.2012.043973.

[56] Contò, F., Fiore, M., Vrontis, D., \& Silvestri, R. (2015). Innovative marketing behaviour determinants in wine SMEs: The case of an Italian wine region. International Journal of Globalisation and Small Business, 7(2), 107-124. doi:10.1504/IJGSB.2015.071181.

[57] Farroq, U. (2019). Innovative Marketing-Strategies \& Examples. Available online: https://www.marketingtutor.net/innovativemarketing/ (accessed on April 2021).

[58] Eurotel Hospitality, (2019). Touch and Dine. Available online: https://eurotel.gr/\%CF\%80\%CF81\%CE\%BF\%CF\%8 A\%CF\%8C\%CE\%BD/touch-and-dine/ (accessed on April 2021).

[59] Sundbo, J. (2009). Innovation in the experience economy: A taxonomy of innovation organizations. Service Industries Journal, 29(4), 431-455. doi:10.1080/02642060802283139.

[60] Carlborg, P., Kindström, D., \& Kowalkowski, C. (2014). The evolution of service innovation research: A critical review and synthesis. Service Industries Journal, 34(5), 373-398. doi:10.1080/02642069.2013.780044.

[61] Volo, S. (2012). A consumer-based measurement of tourism innovation. Innovation in Hospitality and Tourism, 6(3/4), 73-87. doi:10.1300/J162v06n03_05. 
[62] Pikkemaat, B., \& Peters, M. (2012). Towards the measurement of innovation- a pilot study in the small and medium sized hotel industry. Innovation in Hospitality and Tourism, 4(6), 89-112. doi:10.1300/J162v06n03_06.

[63] Camisón, C., \& Monfort-Mir, V. M. (2012). Measuring innovation in tourism from the Schumpeterian and the dynamiccapabilities perspectives. Tourism Management, 33(4), 776-789. doi:10.1016/j.tourman.2011.08.012.

[64] Vergori, A. S. (2014). Measuring innovation in services: the role of surveys. Service Industries Journal, 34(2), $145-161$. doi:10.1080/02642069.2013.763343.

[65] Morrar, R. (2014). Innovation in Services: A Literature Review. Technology Innovation Management Review, 4(4), 6-14. doi:10.22215/timreview780.

[66] Hjalager, A. M. (2002). Repairing innovation defectiveness in tourism. Tourism Management, 23(5), 465-474. doi:10.1016/S0261-5177(02)00013-4.

[67] Orfila-Sintes, F., Crespí-Cladera, R., \& Martínez-Ros, E. (2005). Innovation activity in the hotel industry: Evidence from Balearic Islands. Tourism Management, 26(6), 851-865. doi:10.1016/j.tourman.2004.05.005.

[68] Weiermair, K. (2004). Product improvement or innovation: what is the key to success in tourism? In Innovation and Growth in Tourism: Vol. Lugano, Sw (pp. 53-69). OECD Publishing, Paris, France.

[69] Hjalager, A. M. (2010). A review of innovation research in tourism. Tourism Management, 31(1), 1-12. doi:10.1016/j.tourman.2009.08.012.

[70] Alonso-Almeida, M. del M., Marimon, F., \& Bernardo, M. (2013). Diffusion of quality standards in the hospitality sector. International Journal of Operations and Production Management, 33(5), 504-527. doi:10.1108/01443571311322706.

[71] Dzhandzhugazova, E. A., Blinova, E. A., Orlova, L. N., \& Romanova, M. M. (2016). Innovations in hospitality industry. International Journal of Environmental and Science Education, 11(17), 10387-10400.

[72] Jones, P. (1996). Managing hospitality innovation. Cornell Hotel and Restaurant Administration Quarterly, 37(5), 86-95. doi:10.1016/0010-8804(96)88979-8.

[73] Walder, B. (2006). Sources and determinants of innovations- the role of market forces. In B. Walder, K. Weiermair, K., \& A. S. Perez (Eds.), Innovation and Product Development in Tourism: Creating Sustainable Competitive Advantage. Erich Schmidt Verlag, Berlin, Germany.

[74] Ottenbacher, M., \& Gnoth, J. (2005). How to develop successful hospitality innovation. Cornell Hotel and Restaurant Administration Quarterly, 46(2), 205-222. doi:10.1177/0010880404271097.

[75] Djellal, F., \& Gallouj, F. (2008). A model for analysing the innovation dynamic in services: The case of "assembled" services. International Journal of Services, Technology and Management, 9(3-4), 285-304. doi:10.1504/IJSTM.2008.019702.

[76] Djellal, F., \& Gallouj, F. (2010). Services, innovation and performance: general presentation. Journal of Innovation Economics \& Management, $\mathrm{n}^{\circ}$ 5(1), 5-15. doi:10.3917/jie.005.0005.

[77] Biege, S., Lay, G., Zanker, C., \& Schmall, T. (2013). Challenges of measuring service productivity in innovative, knowledgeintensive business services. Service Industries Journal, 33(3-4), 378-391. doi:10.1080/02642069.2013.747514.

[78] Divisekera, S., \& Nguyen, V. K. (2018). Determinants of innovation in tourism evidence from Australia. Tourism Management, 67, 157-167. doi:10.1016/j.tourman.2018.01.010.

[79] Wilson, J. Q. (1966). Innovation in organization: Notes towards a theory. In J. D. Thompson (Ed.), Approaches in organizational design (pp. 16-22). University of Pittsburgh Press, Pittsburgh, Pennsylvania, United States

[80] Shepard, H. A. Innovation-Resisting and Innovation-Producing Organizations. The Journal of Business, 40(4), 470-477.

[81] Tornatzky, L. G., Eveland, J. D., Boylan, M. G., Hetzner, W. A., Johnson, E. C., Roitman, D., \& Schneider, J. (1983). The process of technological innovation: Reviewing the literature, National Science Foundation, University of Michigan, Michigan, United States.

[82] Damanpour, F. (1987). The Adoption of Technological, Administrative, and Ancillary Innovations: Impact of Organizational Factors. Journal of Management, 13(4), 675-688. doi:10.1177/014920638701300408.

[83] Van De Ven, A. H., \& Rogers, E. M. (1988). Innovations and Organizations: Critical Perspectives. Communication Research, 15(5), 632-651. doi:10.1177/009365088015005007.

[84] Rogers, E. M. (2010). Diffusion of innovations. Simon and Schuster, New York, United States.

[85] Marcus, A. A., \& Weber, M. J. Externally-induced innovation. In A. H. V. Ven, H. L. Angle, \& M. S. Poole (Eds.), Research on the Management of Innovation: The Minnesota Studies (pp. 537-559). Oxford University Press, Oxford, United Kingdom.

[86] Rothwell, R. (1994). Towards the Fifth-generation Innovation Process. International Marketing Review, 11(1), 7-31. doi:10.1108/02651339410057491. 
[87] Moore, G. C., \& Benbasat, I. (1991). Development of an instrument to measure the perceptions of adopting an information technology innovation. Information Systems Research, 2(3), 192-222. doi:10.1287/isre.2.3.192.

[88] Davis, F. D. (1989). Perceived usefulness, perceived ease of use, and user acceptance of information technology. MIS Quarterly: Management Information Systems, 13(3), 319-339. doi:10.2307/249008.

[89] Lee, Y., Kozar, K. A., \& Larsen, K. R. T. (2003). The Technology Acceptance Model: Past, Present, and Future. Communications of the Association for Information Systems, 12(50), 752-780. doi:10.17705/1cais.01250.

[90] Chadee, D. D., \& Mattsson, J. (1996). An empirical assessment of customer satisfaction in tourism. Service Industries Journal, 16(3), 305-320. doi:10.1080/02642069600000030.

[91] Orfila-Sintes, F., \& Mattsson, J. (2009). Innovation behavior in the hotel industry. Omega, 37(2), 380-394. doi:10.1016/j.omega.2007.04.002.

[92] Grissemann, U. S., Pikkemaat, B., \& Weger, C. (2013). Antecedents of innovation activities in tourism: An empirical investigation of the Alpine hospitality industry. Tourism: An International Interdisciplinary Journal, 61(1), 7-27. 